\title{
IMPACT OF ADVERTISEMENT OF TELECOMMUNICATION COMPANIES ON CUSTOMERS SATISFACTION - EVIDENCE FROM MOBILE USERS IN MAIMANA CITY AFGHANISTAN
}

\author{
Erkin Qachmas \\ Department BBA, Faculty of Economics \\ Faryab University, Maimana, Faryab, Afghanistan
}

\begin{abstract}
Mobile users would be satisfied while they earn more telecom facilities and also it is the responsibilities of the service providers to keep their users imposing the interesting, fascinating, amazing and attracting products and services. Satisfaction is feeling states that come from the fulfillment of one's requirements, hope, and want. To indicate the satisfaction of the mobile users in Maimana city we use the descriptive and correlation analysis. The output was analyzed in SPSS ver.24. After testing the reliability of data the Cronbach Alpha is 0.824. The hypothesis testing shows that there is a significant impact of advertising of telecom providers on customers' satisfaction.
\end{abstract}

Keywords - Customer, Advertisement, Satisfaction, Loyalty, Brand, Telecommunication Sectors AWCC, Roshan, MTN, Etisalat,

\section{INTRODUCTION}

Satisfaction is feelings derived from the fulfillment of one's requirements, hope, and want. The business has also the idea of satisfaction. Getting more or equally than expected one feels good and interested. That state could be named his or her satisfaction. Customers have certain standards about the performance of this or that product and its possible price range. Proves to be is better than expected, customers grow faithful to it. The satisfaction of customers is essential for a successful company. Customer satisfaction is a priority for the businesses today, especially for the companies. That is working beyond the boundaries. The satisfied customer means stable advertising and goodwill of the companies, for this reason, they are now doing their best to satisfy the customer to the maximum level (Daniel, Ashar, \& Hafiz, 2008, p. 550). Satisfaction is considered to be a subjective issue and scholars have provided different definitions. Existing literature indicates a range of varying definitions of satisfaction, therefore lack of agreement in defining this term restricts the

\author{
Wahidullah Enayat \\ Department Finance and Banking, Faculty of Economics \\ Faryab University, Maimana, Faryab, Afghanistan
}

empirical research of customer satisfaction and its contribution to the given context. Researchers also face difficulties while to selecting a suitable definition of satisfaction for a specific context, measurement of satisfaction and its interpretation (Giese \& Cote, 2000, p. 1).

\section{LITERATURE REVIEW AND CONCEPTUAL FRAME-WORK}

\section{A. Concept of Customer Satisfaction and Adertisement}

In spite of the fact that satisfaction and, in particular, customer satisfaction is problematic to define there exist certain aspect which is commonly mentioned in the professional literature. The interpretations are transferred in different ways, including by these aspects we mean emotionality, based on comparing inputs and rewards, cognitive evaluations, cumulative evaluation, and sets of attitudes. Satisfaction is generally presented as an attitude characterizing multiple satisfaction judgments. From this point of view, customer satisfaction can be treated as an appropriate assessment of any issue related to consumption which is done by every person individually. Thus, satisfaction is explored as a purchase outcome, whereby customers correlate benefits and costs with foreseen subsequences. Oliver (1997) characterized satisfaction as a feedback to the assessment process. This is illustrated by Oliver's interpretation of satisfaction as follows: "satisfaction is the customer enforcement response" (Ondrejkova, 2005, p. 8).

(Appiah-Gyimah, et al. MAY 2011) in their research Customer Satisfaction in the Outdoor Advertising Industry: A Case of Alliance Media Ghana Limited used multiple regression analysis to find out which of the service quality variables had significant impact on customer satisfaction. The results shown that service quality indicators such as responsiveness and empathy significantly impact on customer satisfaction. Based on these findings, it is recommended that management should develop strategies to enhance its service quality delivery. (Loke, et al. 2011) in the research Service 


\section{International Journal of Engineering Applied Sciences and Technology, 2020 \\ Vol. 5, Issue 6, ISSN No. 2455-2143, Pages 72-78 \\ Published Online October 2020 in IJEAST (http://www.ijeast.com)}

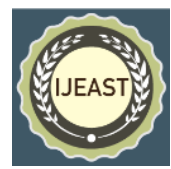

Quality and Customer Satisfaction in a Telecommunication Service Provider they used gap analysis to define the perceived importance and satisfaction on each element of service quality, and regression analysis was conducted to test the link between service quality and levels of customer satisfaction. Results specified that reliability, responsiveness, assurance and empathy significantly positively influenced customer attitudes in terms of satisfaction and loyalty.

(Nasir, Mushtaq and Rizwan 2014) in the study employs several statistical techniques, containing reliability, factor and regression analysis. The epistemology of the study was mainly qualitative and included 170 citizens of Pakistan through a questionnaire run survey and factor analysis was further applied to confirm the results. This study acknowledges service quality positively affecting customer satisfaction with perceived price acting as a moderating variable. In addition to that service quality also has an important positive influence on trust. Customer satisfaction is a strong variable effecting customer loyalty and trust positively. Therefore, it could be hypothesized that users with high rated perception of service quality and satisfaction also mostly revealed repurchase committed and strong loyalty towards the services. (Karim, Shehzad and Arshad March 2017) in their study (Effects of TV Advertising of Cellular Companies on User's Behavior) aims to investigate that whether TV advertising of cellular companies influences the user's behavior. Data is collected from both 300 male and female of Lahore, Islamabad and Gujrat cities of Pakistan through survey method and sampling technique is used for this purpose. For statistical analysis Chisquare technique is used. The results specify that there is a significant correlation between the advertisement influence and in purchasing the brand, but not much adequate circumstances and some variables for switching their mobile service providers. (Leelakulthanit and Hongcharu, 2011) researched the factors of customer satisfaction by distribution of 400 samples for cell phone users in Thailand. The study found that advertising value, quality of customer service at shops and company image play the most important role in defining customer satisfaction. (Alam, Khan, and Uddin, 2010) study on 60 university students in Bangladesh those were also cell phone users, to find the factors in selecting telecom companies. The outcomes of that research shows two factors, brand image and perceived call rates, to have the most effects on the consumers' selection choice of a telecom company in Bangladesh. (Bugel and Verhoef, July 2011) studied commitment to companies, in The Netherlands, using the psychological investment model. The study tested the connections between customer and company in five areas: the banking sector, health insurance, supermarkets, mobile telecom providers, and the automotive industry. The study recruited 300 respondents for each sector. With regard to satisfaction, the result of the research suggests that satisfaction shows a significant role in defining customer commitment for mobile companies and a positive correlation between enlightening customer satisfaction and attaining customer loyalty. (Jahanzeb, Fatima, and Khan, March 2011) studied customer loyalty in the telecomm sector in Pakistan, interviewing 146 mobile users. The research found that customer loyalty is designed mainly by: trust, service quality, employee's loyalty, and changing cost. The results of study agree, partly, with a research by (Rosemond and Agyapong, November 2010) of interviewing of 460 Vodafone telecom users in Ghana. This research determined that satisfaction does not necessarily lead to loyalty, where the service quality has been found to be intensely and positively correlated with loyalty. However, it can be observed from the results of this research that customer satisfaction is already built into service quality. The importance of service quality in the selection and decision for a telecom company was also highlighted by (Rahman, Khan, and Mahmudul Haque, 2012) who showed a research of 400 mobile telecom users from key cities in Malaysia. This study determined that network quality is one of the significant factors in whole service quality. Furthermore, to service quality, the research resulted that price plays a significant role in the selection standards for telecom provides in Malaysia. (Gupta and Sharma, 2009) studied that in order to hold customers and encourage new users, telecom providers must provide facilities with best quality without any unseen price, the two most significant determinants of consumer satisfaction.

(Ahmed, et al., 18 Sep 2010) researched the customer retention through the quality of Short Message Services (SMS), using 331 university students using SMS of any telecom company in Pakistan. Their results show that service quality has an important relationship to customer retention.

(Bin Nooh, et al., June 2014) has found the effect of unethical advertising principles that effects to the next creation. The research inverse that deceptive and inappropriate advertising makes undesirable trust in the consciousness of people mainly teenagers or young's in Malaysia.

\section{B. Theoretical Area of Satisfaction}

To clarify customer satisfaction there are a number of theoretical approaches which have been applied. The theories can be commonly categorized into three groups: Expectancy disconfirmation, Equity, and Attribution. The expectancy disconfirmation theory advises that consumers form satisfaction arbitration by measuring certain product/service. There are four psychological theories which were developed by Anderson that can be used to define the impact of expectancy or satisfaction.

\section{Measurement of Satisfaction}

The connection between what was expected from the product or service's and their final usage is the nature of satisfaction, which can be measured. This measure has been characterized as the 'confirmation and disconfirmation' process. First, customers would form predictions previous to purchasing a product or service. Second, utilization of or participation in the 


\section{International Journal of Engineering Applied Sciences and Technology, 2020 \\ Vol. 5, Issue 6, ISSN No. 2455-2143, Pages 72-78 \\ Published Online October 2020 in IJEAST (http://www.ijeast.com)}

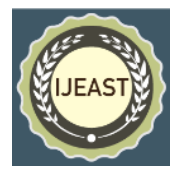

product or service generates a level of comprehending quality that is impressed by expectations (Safiek, 2009, p. 90).

Most companies hold a highly complementary view of themselves, saying that consider they are the greatest and they don't have an unhappy customer. The reality is, 96 percent of unhappy customers don't complain. One financial training service found out that most of the unhappy customers just simply leave never come back. Customer satisfaction plays an important role in the business. Measuring customer loyalty, identifying unhappy customer lead to decrease churn and increase revenue.

There are two determinations of satisfaction:

a. Subjective (e.g. customer needs, emotions)

b. Objective (e.g. product and service feature)

There have been various studies that consider attributes applying to the hospitality that travelers may find influential regarding customer satisfaction. Distinct concepts of satisfaction are service quality and customer although they are closely related (Safiek, 2009, p. 91).

\section{Elements of Customer Satisfaction}

Customer satisfaction is a marketing duration that measures how products or services equipped by a company meet or exceed a customer's expectation. Customer satisfaction is important because it implements trade and business partners with a metric that they can handle to administer and improve their businesses.

The Six Elements why Customer Satisfaction is so important

- It's the best index of customer repurchase purpose and loyalty

- It's a point of separation

- It diminishes customer churn

- It raises customer lifetime value

- It reduces pessimistic word of mouth

- It's inexpensive to absorb customers than achieve new ones

\section{AN OVERVIEW OF TELECOMMUNICATION IN AFGHANISTAN}

It is common knowledge that the telecom companies are undoubtedly one of the important elements in the economic development of any country. The necessity for improving the infrastructure of these services has been increasing day by day because privatization ameliorates the interior turnover of the sector. It is well-known that the private sector is more fruitful and beneficial than the public one in both developed and developing countries.

In a number of developing countries (Afghanistan being one of them) telecommunication sector has been under the state control for many years, therefore the level of development is low in contrast to more developed countries where this sector was made private a long time ago. The main conflict lies in the fact that the technological development of the industry at the global level is very high, while the economic conditions and the lack of government resources of developing countries make it difficult for developing countries to adapt to these changes, both technically and economically. Thus the need for privatization is high, this also being the cause to change the industry. However, the political and economic developments that took place in the sector were diverse both in the scope and nature.

From 2003 through the end of 2014, 90\% of the local regions have been engaged under telecommunication and information inclusion. Up to the present time, there are 23.21 million mobile phone operators in the country. Approximately 2,413,610,672.34 US dollars have been funded by the department. Annual income from telecom portion to the government is over 200 million dollars. In ICT sector (information and communications technology) 204,000 persons, including occupational, non-occupational, entrepreneurs and telecommunication paraphernalia sellers are provided work chances (MCIT, 2016)

The status of the telecommunication branch is different in developed and developing countries in many ways. In developing countries (including in Afghanistan), companies usually have a low share as owners and for this reason, they are not interested in investing in developing networks and increasing their expenditures in general. Is intensification to available in several hamlets because information is hard to collect it decreases chance so, there is the downward capability to salary for infrastructure rollout because of small revenue. In developing countries telecommunication has a positive and significant impact on economic growth; in contrast to developed countries, this impact is twice larger. Mobile telephones also provide a considerable growth benefit for excellent earning countries through the same time cycle (Waverman, Meschi, \& Fuss, 2001, p. 2).

A competition strategy is a lengthy proposal of a company to increase its competitive advantage upon its competitors in the industry. This plays a further substantial role in the telecommunication sector, especially in developing countries because the telecommunication sector is one of the more dynamic and innovative drivers in the economy and competition has prevented the rationalization for many surfaces of sector exact legislation (Porter, 1990). From the past decade, Afghanistan had a hardly efficient post-war infrastructure with basically no telecom services. The telecom sector was officially "born" in April 2002, when the first private telecom company Afghan Wireless Communications Company (AWCC) was established to offer mobile services. Since then, the telecom sector has observed exceptional and remarkable growth (Hamdard, 2012, p. 12). This was during the government of Hamid Karzai and telecommunications contributed to social and economic benefits of the country. The Telecom sector provided more to the GDP of the national economy and performed revenue to the government in the form of taxation. As a result of the expenses on the part of the companies, it was possible for the government to generate occupation opportunities which lead to higher living standards, and economic and social development. As long as 


\section{International Journal of Engineering Applied Sciences and Technology, 2020 \\ Vol. 5, Issue 6, ISSN No. 2455-2143, Pages 72-78 \\ Published Online October 2020 in IJEAST (http://www.ijeast.com)}

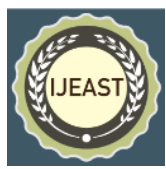

this was a newly established sector with high growth rates its development was higher than that of some neighboring countries (Baharustani, 2013, p. 3). Thus, due to the speedy developments in the infrastructure, services, policy, the telecom sector grew to one of the main revenue creating sectors in Afghanistan (Hamdard, 2012, p. 8).

Due to geographical location of Afghanistan which most parts are surrounded by mountains and most Afghans have been spread from the facilities of telecommunication services which very important issue for the reconstruction of Afghanistan, therefore, Afghanistan's ministry of communications and information technology departments included the first public policies for the telecommunication sector and incentivizing private companies to invest in the telecommunication sector. Since then, the Company Afghan Wireless, Roshan, MTN these groups, has started to its activities afterward, today 80 percent of the country is covered by the telecommunication sector and it is implementing by the Afghans in 34 provinces of Afghanistan (MCIT, 2016).

According to (Hamdard, 2012), this sector has been absorbed above $\$ 1.8$ billion in total investments as of 2012 compared to $\$ 600$ million in 2006. Simultaneously, during the time concerning evolution tendency in the country, the telecom sector has created above 110,000 direct and indirect job occasions all over the country contrast to 40,000 jobs in 2006.

Afghans should be attributed to the fast demand-driven increase in the telecom sector as the end-users and buyers of these services, financiers have played a considerable character in structure the essential infrastructure and also the Afghan Government and the Ministry of

Communication and Information Technology as a facilitator, policymaker, regularize and maker of infrastructure have played an actual optimistic part.

One of the main preference discussions for the sector since 2002 is building a sufficient national telecom infrastructure. Telecom infrastructure has the large part of the total investment the private sector like Afghan Wireless Communication Company, Roshan ,Etisalat, MTN, and one government sector Salaam they are the huge financiers in the country, pursue by the Afghan Government with support of organizations such as the World Bank and the (USAID). ${ }^{1}$

The rising competition leads the telecom market for supplying low-priced makes a better quality of service and this lead to a decrease in the price of telecom services. According to Hamdard (2012), at first SIM cards sold for more than \$250 in 2002, and now it is obtainable for less than one US dollar. Also, there is a fallen to local cost for using a mobile telephone more than $500 \%$ from 18 Afs $(\$ 0.36)$ per minute in 2003 to 3 Afs $(\$ 0.06)$ in 2012 . The international calling tariff has also reduced from 100 Afs (\$2) per minute in 2003 to an average of 15 Afs (\$0.30) in 2012 (Hamdard, 2012, p. 10).

\footnotetext{
${ }^{1}$ United States Agency for International Development
}

\section{THE MAIN FINDINGS OF THE RESEARCH}

The results of empirical data obtained from field research based on an individual interview with the customers of four big and active telecommunication companies ${ }^{2}$ in Maimana city located at north region of Afghanistan. For the analysis of the data we used SPSS software. Frequency distributions and descriptive analysis for socio - economic factors and stepwise regression have done to reach the goal.

\section{Hypothesis}

H1: Advertisement has a positive impact on customer satisfaction.

\section{Socio - Economic Factors of Respondants}

The field research was conducted in the Maimana city of Faryab province. In total 250 customers from different professions and social groups were identified and selected as a target sample. To provide a better understanding of telecom services' customers in Afghanistan, in particular, Maimana City, their demographic characteristics such as age, marital status, education background, and level of income represented. Out of 250 interviewees 30 percent of respondents were female and the remaining 70 percent were male. From those 90 percent were in the working age, 18 to 65 , and only 10 percent were either below 18 or elders above 65 years old. 37 percent of responded were single and the remaining 60 percent were married and 3 percent were not defined. The education level of interviewees found that 83 persons had higher education, 97 persons were high school, 40 persons had secondary school, and 30 persons with primary school.

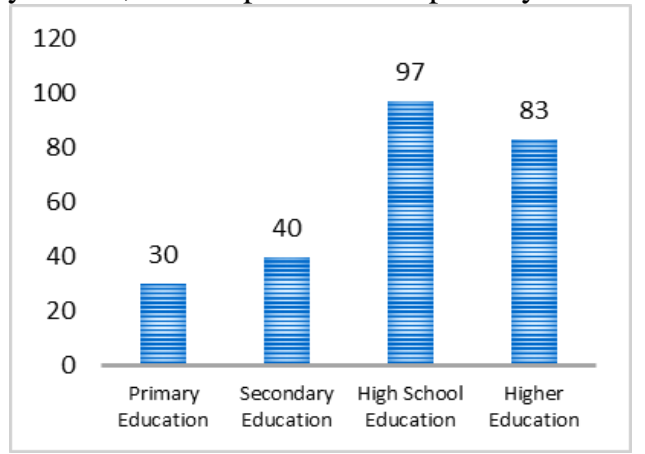

Figuer 1: Educational level of Interviewees

\section{Income Profile of Respondants}

From 250 respondands $13.6 \%$ does not have income (they just depend on their family income), $27.6 \%$ have less than 5000AFs, $24.8 \%$ in interval of 5000 AFs -10000 AFs, $18 \%$ in interval of $10000 \mathrm{AFs}-20000 \mathrm{AFs}, 13.6 \%$ in interval of $20000 \mathrm{AFs}-30000 \mathrm{AFs}$ and $2.4 \%$ have more than $30000 \mathrm{AFs}$ income.

2) AWCC Roshan
AFG


Table 1: The Income Profile interviewees (amount in terms of AFs)

\begin{tabular}{|c|c|c|c|}
\hline $\begin{array}{c}\text { Level of } \\
\text { Income }\end{array}$ & Frequency & Percent & $\begin{array}{c}\text { Cumulative } \\
\text { percent }\end{array}$ \\
\hline $\begin{array}{c}\text { No } \\
\text { income }\end{array}$ & 34 & 13.6 & 13.6 \\
\hline $\begin{array}{c}\text { Less than } \\
5000\end{array}$ & 69 & 27.6 & 41.2 \\
\hline $\begin{array}{c}5,000- \\
10,000\end{array}$ & 62 & 24.8 & 66 \\
\hline $\begin{array}{c}10,000- \\
20,000\end{array}$ & 45 & 18 & 84 \\
\hline $\begin{array}{c}20,000- \\
30,000\end{array}$ & 34 & 13.6 & 97.6 \\
\hline $\begin{array}{c}\text { More than } \\
30000\end{array}$ & 6 & 2.4 & 100 \\
\hline Total & 250 & 100 & \\
\hline
\end{tabular}

Monthly Cost of Telecommunication of Respondents (amount in term of AFs)

123 respondents cost 50 AFs -100 AFs, 72 respondents cost 100 AFs - 500 AFs, 38 respondents cost 500AFs - 1000AFs and 17 respondents cost more than 1000AFs.

Table 2: Money Spent by Customers per Month for Telecom Services (in AFS)

\begin{tabular}{|c|c|c|c|}
\hline $\begin{array}{c}\text { Monthly Cost of } \\
\text { Telecommunication }\end{array}$ & Frequency & Percent & $\begin{array}{c}\text { Cumulative } \\
\text { percent }\end{array}$ \\
\hline $50-100$ & 123 & 49.2 & 49.2 \\
\hline $100-500$ & 72 & 28.8 & 78 \\
\hline $500-1000$ & 38 & 15.2 & 93.2 \\
\hline More than 1000 & 17 & 6.8 & 100 \\
\hline Total & 250 & 100 & \\
\hline
\end{tabular}

Table 3 :Type of Customers Based on their Economic Activity

\begin{tabular}{|c|c|c|c|}
\hline $\begin{array}{c}\text { Terms of } \\
\text { Activity }\end{array}$ & Frequency & Percent & $\begin{array}{c}\text { Cumulative } \\
\text { percent }\end{array}$ \\
\hline Do not work & 32 & 12.8 & 12.8 \\
\hline $\begin{array}{c}\text { Have private } \\
\text { business }\end{array}$ & 121 & 48.4 & 61.2 \\
\hline $\begin{array}{c}\text { Work with Gov- } \\
\text { organization }\end{array}$ & 67 & 26.8 & 88 \\
\hline $\begin{array}{c}\text { Work with } \\
\text { NGOs }\end{array}$ & 30 & 12 & 100 \\
\hline Total & 250 & 100 & \\
\hline
\end{tabular}

The largest percentage of the economic activities of the respondents express by private business $48.4 \%$ and lowest percentage of the economic activities of the respondents express by NGO employees $12 \%$.
Composition of Telecom Services in Afghanistan

Roshan, AWCC, Etisalat, and MTN are the private telecommunication Companies and Afghan Telecom is the state-owned company with wireless service of SALAAM.

Thirty-three percent of the customers use telecom services of only one company and the remaining Sixty-seven percent of them prefer to use the services of different companies at the same time. Forty-two percent of people use two SIM cards so most of them with two SIM cards because of security problems in some areas of the country the foundation of networks will be broken by Taliban and some other reasons:

1. Separating work issues with the family issues for that purpose people who work in an office (Governmental and nongovernmental) more users of two SIM cards, therefore, one is from the office.

2. Using two servers causes to use the company welfare and as well as economic benefits because telephone call from one network to the same network is much cheaper than another network.

3. Innovation and advertisement induce people to use the other SIM cards and custom the benefits.

\section{Composition of Telecom Services}

Due to security problem since 2 years the state Telecom company (Afghan Telecom) does not offer any servises in Maimana City, therefore, the 4 big companies offering services. Customers are mostly liked to use Roshan for their voice calls and AWCC is used for Internet services and the services of the other companies are used depend on custome perceptions.

Table 4: Composition of Telecom Services used by Customer

\begin{tabular}{|c|c|c|c|}
\hline Name of Company & Frequency & Percent & $\begin{array}{c}\text { Cumulative } \\
\text { percent }\end{array}$ \\
\hline AWCC & 38 & 15.2 & 15.2 \\
\hline Roshan & 48 & 19.2 & 34.4 \\
\hline Etisalat & 15 & 6 & 40.4 \\
\hline MTN & 17 & 6.8 & 47.2 \\
\hline AWCC\& Roshan & 32 & 12.8 & 60 \\
\hline AWCC \& Etisalat & 15 & 6 & 66 \\
\hline AWCC \& MTN & 8 & 3.2 & 69.2 \\
\hline AWCC, Roshan \&Etisalat & 10 & 4 & 73.2 \\
\hline AWCC, Roshan \&MTN & 5 & 2 & 75.2 \\
\hline AWCC, Roshan, Etisalat \& MTN & 7 & 2.8 & 78 \\
\hline Roshan \& Etisalat & 15 & 6 & 84 \\
\hline Roshan \& MTN & 17 & 6.8 & 90.8 \\
\hline Roshan, Etisalat \&MTN & 12 & 4.8 & 95.6 \\
\hline Etisalat \&MTN & 11 & 4.4 & 100 \\
\hline Total & 250 & 100 & \\
\hline
\end{tabular}




\section{International Journal of Engineering Applied Sciences and Technology, 2020 \\ Vol. 5, Issue 6, ISSN No. 2455-2143, Pages 72-78 \\ Published Online October 2020 in IJEAST (http://www.ijeast.com)}

\section{Impact of Band on Customers' Perceptions}

On average 17 respondents were strongly disagree with the impact of brands, 36 respondents were disagreeing with the impact of brands, 57respondents were natural with the impact of brands, 117 respondents were agreeing with the impact of brands and 23 respondents were strongly agree with the impact of brands.

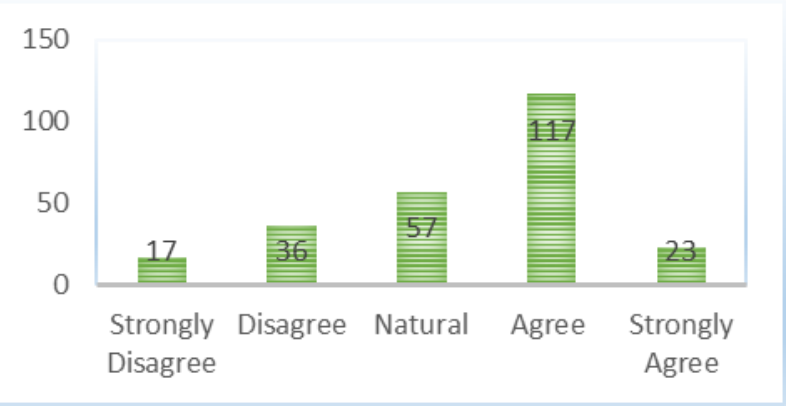

Figure 2: The Impact of Brand

\section{Customers' Loyalty Factor}

Most of the respondents express their feelings about the loyalty to the telecom service providers, few of them were strongly not loyal and some of them did not answer for the given question. The following table shows the customers' loyalty factor to the service providers.

Table 5: customers' loyalty factor

\begin{tabular}{|c|c|c|c|c|}
\hline $\begin{array}{c}\text { Loyality of } \\
\text { Customer }\end{array}$ & AWCC & Roshan & Etisalat & MTN \\
\hline Strongly Not Loyal & $10 \%$ & $12 \%$ & $24 \%$ & $21 \%$ \\
\hline Not Loyal & $7 \%$ & $5 \%$ & $12 \%$ & $14 \%$ \\
\hline Natural & $27 \%$ & $24 \%$ & $27 \%$ & $23 \%$ \\
\hline Loyal & $41 \%$ & $48 \%$ & $32 \%$ & $33 \%$ \\
\hline Strongly Loyal & $11 \%$ & $11 \%$ & $2 \%$ & $7 \%$ \\
\hline Not Defined & $4 \%$ & & $3 \%$ & $2 \%$ \\
\hline & $100 \%$ & $100 \%$ & $100 \%$ & $100 \%$ \\
\hline
\end{tabular}

The Motivation of Customers by Advertising of Products of Service Providers.

The advertisement motived 136 respondants, and the lowest numbers of responds regarding is the strongly not motive by advertising is liked by respondants 7 , while, the most motive is ranked $3^{\text {rd }}$ and natural factor is ranked $2^{\text {nd }}$ in the survey.

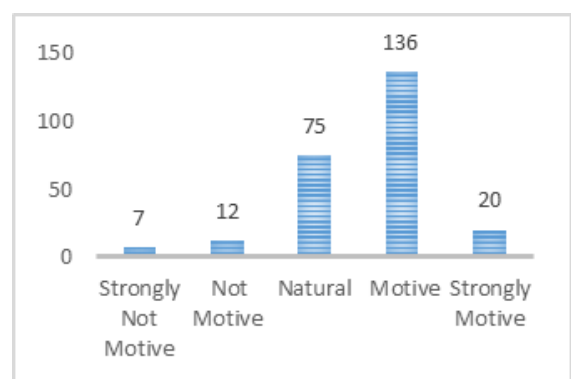

Figure 3: Advertisement Motivating Customers

Reliability Analysis

To understand that the data would be reliable or not, we test the Cronbach Alpha and the result is over 0.79 the standards $(0.824)$ so the data is reliable.

Table 6: Cronbach's Alpha

\begin{tabular}{|l|c|}
\hline \multicolumn{1}{|c|}{ Scale } & Cronbach's Alpha \\
\hline $\begin{array}{l}\text { Customer satisfaction from advertising the } \\
\text { companies }\end{array}$ & 0.824 \\
\hline
\end{tabular}

\section{Correlation Analysis}

The correlation analysis expressed in the following table. Correlation of brand company with loyalty of in not significant in $a=0.05$ but it is significant while the alpha is $(a=0.10)$ then is significant. The HO is not reject means that there is no significant relation between brand of company and loyalty of customers. There is significant correlation between brand of company and advertisement to motive the customer is $\mathrm{r}=0.039$, there is also a significant correlation was shown in the analysis the loyalty of customers and the advertisement to motive the customer by $r=0.0435$.

Table 7: Correlation of variables

\begin{tabular}{|c|c|c|c|c|}
\hline Variables & $\begin{array}{c}\text { Rating } \\
\text { Factor }\end{array}$ & Brand & loyalty & $\begin{array}{c}\text { Ads } \\
\text { Motivation }\end{array}$ \\
\hline Brand & 3.57 & 1 & $\begin{array}{c}.285^{* *} \\
\mathrm{R}=0.072\end{array}$ & $\begin{array}{c}.286^{* *} \\
\mathrm{R}=0.039\end{array}$ \\
\hline loyalty & 3.46 & $\begin{array}{c}.285^{* *} \\
\mathrm{R}=0.072\end{array}$ & 1 & $\begin{array}{c}.349^{* *} \\
\mathrm{R}=0.0435\end{array}$ \\
\hline $\begin{array}{c}\text { Ads } \\
\text { Motivation }\end{array}$ & 3.15 & $\begin{array}{c}.286^{* *} \\
\mathrm{R}=0.039\end{array}$ & $\begin{array}{c}.349^{* *} \\
\mathrm{R}=0.0435\end{array}$ & 1 \\
\hline
\end{tabular}

\section{CONCLUSION}

In Afghanistan there are 5 big telecommunication companies are actively supplying telecommunication services. But in Maimana city there ate just four companies supply telecommunication service. They invest lots of money in the area. The race for the increasing market shares of the companies are very tough. The customers are likely looking to get more facilities to satisfy. The suppliers are trying to provide at least the minimum telecom needs of the users.

The correlation analysis expressed in the outcomes show that the advertisement has the significant relation with band of 


\section{International Journal of Engineering Applied Sciences and Technology, 2020 \\ Vol. 5, Issue 6, ISSN No. 2455-2143, Pages 72-78 \\ Published Online October 2020 in IJEAST (http://www.ijeast.com)}

company $(r=0.039)$ and with loyalty of customer $(r=0.0435)$. The reliablity of the data anlysis with Cronbach's Alpha the result stands 0.824 and indicates the data is reliable. It is recommended that the companies would spends more money on advertising to explore the sevices that they newly launch in the market and also keep the share of the market that they hold.

\section{ACKNOWLEDGEMENT}

We would like to express our sincere gratitude to IJEAST for publishing the paper. To our University, Faryab University administrative and academic bodies, we wish them all the bests. Also we want to thank our colleagues who help us for data collection.

\section{REFERENCE}

1 Ahmed, I., et al, (18 Sep 2010). Does service quality affect students' performance? Evidence from institutes of higher learning. African Journal of Business Management, Vol. 4, No. 12, (pp. 2527-2533).

2 Appiah-Gyimah, R., et al, (MAY 2011). Customer Satisfaction in the Outdoor Advertising Industry: A Case of Alliance Media Ghana Limited. International Journal of Marketing Studies, Vol. 3, No. 2, (pp. 82-91)

3 Baharustani, R. (2013). Study of Afghan Telecom industry. Afghanistan Investent Support Agency, (PP. 144).

4 Beard, R. (2014, january 20). blog. Retrieved from (pp. 13)

5 Bin Nooh, et al. (June 2014). Advertising Ethics: A Quranic Perspective. International Journal of Liberal Arts and Social Science, Vol. 2, No. 5, (pp. 77-82).

6 Bugel, M., and Verhoef, P. (July 2011). Customer intimacy and commitment to relationships with firms in five different sectors: Preliminary evidence. Journal of Retailing and Consumer Services, Vol. 18, No4, (pp. 247258).

7 Daniel, A., Ashar, M., and Hafiz, I.-U.-R. (2008). An Impact of Emploee Satisfaction on Customer Satsifaction in Service Sector of Pakistan. Jornal of Scientific Research, Vol. 2, No. 10, (pp.548-561).

8 Giese, J., and Cote, J. (January 2000). Defining Consumer Satisfaction. Academy of Marketing Science Review.

9 Gupta , J., and Sharma, R. (2009). Production technology and quality characteristics of mead and fruit-honey wines : A review. National Product Radians, Vol. 8, No. 4, (pp. 345-355).

10 Hamdard, J. (2012). The State of Telecommunication and Internet in Afghanistan Six years Later (2006 - 2012). Kabul: U. S. Agency fo international Development.
11 Jahanzeb, S., Fatima, T., and Khan, M. (March 2011). An empirical analysis of customer loyalty in Pakistan's telecommunication industry. Journal of Database Marketing and Customer Strategy Managment, Vol. 15, No. 1, (pp. 5-15).

12 Karim, L., Shehzad, M., \& Arshad, S. (March 2017). Effects of TV Advertising of Cellular Companies on User's Behavior. International Journal of Humanities and Social Science, Vol. 7, No. 3, (pp. 196-201).

13 Leelakulthanit, O., and Hongcharu, B. (2011). Factors that impact customer satisfaction: Evidince from the Thailand mobile cellular network industry. International Journal of Management and MArketing Research, Vol. 4, No. 2, (pp. 67-76).

14 Loke, S.-P., Taiwo, A., Salim, H., \& Downe, A. (2011). Service Quality and Customer Satisfaction in a Telecommunication Service Provider. International Conference on Financial Management and Economics. Vol. 11, (pp. 24-29). Singapore: IACSIT Press.

15 MCIT. (4.11.2016). Telecom Sector Recent Achievement. Retrieved 9 5, 2020, from Ministary of Communication and Information Technology: http://mcit.gov.af/en/page/public-document/6005

16 Nasir, A., Mushtaq, H., \& Rizwan, M. (2014). Customer Loyalty in Telecom Sector of Pakistan. Journal of Sociological Research, Vol. 5, No. 1, (pp.449-467).

17 Ondrejkova, S. (2005). MSC.in business performance management. (pp. 1-64).

18 Porter, M. E. (1990). The Competitive Advantages of Nations. The Vodafone Policy Paper Series, (pp. 73-91).

19 Rahman, M., Khan, A., and Mahmudul Haque, M. (2012). A Conceptual Study on the Relationship between Service Quality towards Customer Satisfaction: Servqual and Gronroos's Service Quality Model Perspective. Asian Social Science, Vol. 8, No. 13, (pp.201-210).

20 Rosemond, B., and Agyapong, G. (November 2010). Analysis of the Antecedents of Customer Loyalty of Telecommunication Industry in Ghana: The Case of Vodafone (Ghana). Journal of International Business Research, Vol. 4, No. 1.

21 Safiek, M. (2009). theories of customer satisfaction. (pp. 90-123).

22 Waverman, L., Meschi, M., and Fuss, M. (01. 01. 2001). The Impact of Telecoms on Economic Growth in Developing Countries. The Vodafone Policy Paper Series, (pp. 1-23). 